\title{
Tricuspid Valve Regurgitant Volume
}

National Cancer Institute

\section{Source}

National Cancer Institute. Tricuspid Valve Regurgitant Volume. NCI Thesaurus. Code C127600.

A quantitative measurement of the amount of retrog rade blood flow across the orifice of the tricuspid valve. 